НАУКИ О ЗЕМЛЕ

"НАУКА. ИННОВАЦИИ. ТЕХНОЛОГИИ", № 2, 2019

25.00 .36

УДК 669.00.249

Бегдай И.В.,

Блужина А.С.,

Иваненко К.И.,

Харин К.В.

ГЕОЭКОЛОГИЯ

Северо-Кавказский федеральный университет, г. Ставрополь, Россия

*institutka-aska@mail.ru

\title{
ЭКОЛОГО-ЭКОНОМИЧЕСКИЙ УЩЕРБ ПОЧВАМ В РЕЗУЛЬТАТЕ НЕСАНКЦИОНИРОВАННОГО СКЛАДИРОВАНИЯ ОТХОДОВ
}

Введение:

Материалы и методы исследований:

Результаты исследований и их обсуждение:

Выводы:

Ключевые слова:
Законодательное обеспечение взыскания эколого-экономического ущерба от несанкционированного размещения отходов достаточно разработано и имеет научное экологическое обоснование, под которым подразумевается вмешательство продуктов деструкции в геохимические процессы, ухудшение качественных характеристик почвы, и как следствие снижение ее цены. Взыскание ущерба, причиненного почвам, позволяет реализовывать приоритетный подход восстановления качественных свойств почв до приближенных к первоначальному состоянию. Несанкционированные свалки на землях пос. Каменномостского р. Адыгея, как объект исследования вызывают несомненный интерес, природно-ресурсный потенциал пос. Каменномостский активно вовлечен в развитие рекреационного природопользования и нанесение вреда земельным ресурсам ограничивает возможность использования территории в целях рекреации в доступном объеме. Поскольку, с экологической точки зрения рассматриваемая свалка находится в водоохранной зоне реки, посредствам миграционных процессов факт долгосрочного воздействия не только на почвы, но и на воды реки очевиден, первостепенной задачей становится ее ликвидация и восстановление нарушенного плодородного слоя экологически-безопасными методами, которые в свою очередь требуют финансирования.

Примененные методики полевых, лабораторных исследований и расчета эколого-экономического ущерба являются актуальными и отвечающими действующему природоохранному законодательству и законодательству о единстве средств измерений. Расчет и взыскание эколого-экономического ущерба постепенно становятся эффективными механизмами экономики природопользования.

Рассчитанный показатель эколого-экономического ущерба от размещения несанкционированной свалки отходов в водоохранной зоне р. Белая пос Каменномостский в случае реализации правоприменительной практики, может пополнить федеральный бюджет на 618290,1 руб, бюджет республики Адыгея на 4946320,8 руб, бюджет поселка Каменномостский 6801191,1 руб.

В этой связи следует говорить о необходимости повышения эффективности применения такого механизма, как эколого-экономический ущерб. Экологический вред, причиненный почве, как объекту охраны окружающей среды в результате несанкционированного складирования отходов, выраженный в денежном эквиваленте в правоприменительной практике отвечает целям реализации экологической безопасности в рамках эколого-экономической политики и формирует государственный бюджет природоохранных мероприятий.

почва, эколого-экономический ущерб, бюджет на реализацию природоохранных мероприятий, экологическая безопасность, эколого-экономическая политика. 
Begday I.V.

Bluzhina A.S. Ivanenko K.I. Kharin K.V.

Introduction:

Materials and research methods:

Research results and discussion:

Findings:

Keywords:
North Caucasus Federal University, Stavropol, Russia

institutka-aska@mail.ru

\section{ECOLOGICAL AND ECONOMIC DAMAGE TO SOILS AS A RESULT OF UNAUTHORIZED STORAGE OF WASTE}

\begin{abstract}
Legislative support for the recovery of environmental and economic damage from unauthorized waste disposal is sufficiently developed and has a scientific environmental justification, which implies the intervention of degradation products in geochemical processes, the deterioration of the soil quality characteristics, and as a result its price reduction. Recovery of damage caused to the soil, allows you to implement a priority approach to restore the qualitative properties of the soil to close to the original state. Unauthorized dumps on the lands of the village. Kamennomostsky district. Adygea, as an object of research, is of undoubted interest, the natural resource potential of the village. Kamennomostsky is actively involved in the development of recreational use of natural resources and the damage to land resources, which limits the possibility of using the territory for recreational purposes in an accessible volume. Since, from an environmental point of view, the landfill in question is located in the water protection zone of the river, through migration processes, the fact of a long-term impact not only on the soil, but also on the river's waters is obvious, its primary task is to eliminate it and restore the damaged fertile layer using environmentally-friendly methods. all require funding.
\end{abstract}

The applied methods of field, laboratory research and the calculation of environmental and economic damage are relevant and consistent with the current environmental legislation and legislation on the unity of measuring instruments. The calculation and recovery of environmental and economic damage is gradually becoming effective mechanisms for environmental economics.

The calculated indicator of environmental and economic damage from the placement of an unauthorized waste dump in the water protection zone $r$. White Village. In the case of the implementation of law enforcement practice, Kamennomostsky can replenish the federal budget by $6,182,090$ rubles, the budget of the Republic of Adygea by $4,946,320.8$ rubles, the budget of the settlement of Kamennomostsky $6,801,191.1$ rubles

In this regard, we should talk about the need to improve the effectiveness of the use of such a mechanism as environmental and economic damage. Environmental damage caused to the soil as an object of environmental protection as a result of unauthorized storage of waste, expressed in monetary terms in law enforcement practice, meets the objectives of implementing environmental safety within the framework of environmental and economic policy and forms the state budget for environmental protection measures.

soil, environmental and economic damage, budget for the implementation of environmental measures, environmental safety, environmental and economic policy.

\section{Введение}

Вопросы экологической безопасности Российской Федерации обладают значительной актуальностью в условиях наметившейся новой государственной эколого-экономической политики. Обеспечение экологической безопасности государства основывается на экономическом механизме регулирования природопользования. К основным задачам экономического механизма охраны окружающей среды можно отнести: планирование, финанси- 
рование природоохранных мероприятий и возмешение в установленном порядке вреда, причиненного окружающей природной среде и здоровью человека. Правовой основой возмещения вреда является статья 42 Конституции РФ, регламентирующая право каждого на благоприятную окружающую среду, достоверную информацию о ее состоянии и на возмещение ущерба, причиненного здоровью или имуществу экологическим правонарушением $[2,5]$. Согласно постановлению Пленума Верховного Суда Российской Федерации от 30.11.2017 № 49 «О некоторых вопросах применения законодательства о возмещении вреда, причиненного окружающей среде» говорится о возмещении вреда, причиненного компонентам окружающей среды, в обязательном порядке. Поскольку под экологическим ущербом понимают оцененный экологический вред, очень важна стоимостная оценка экологического ущерба. Как упоминалось ранее, Российская Федерация в последние годы сделала переориентацию политики природопользования в эффективную экологоэкономическую политику. В этом направлении сделаны значительные шаги, так путь смены системы обращения с твердыми коммунальными отходами дает первые положительные результаты. Введение института регионального оператора [10], в рамках реформирования сферы обращения с отходами, подает надежды решения вопросов несанкционированного размещения отходов. На регионального оператора возложена обязанность и ответственность по ликвидации несанкционированных мест складирования отходов, однако ущерб почвам, как объекту охраны окружающей среды будет возмещаться либо собственником земельного участка, либо установленным виновным лицом [1]. Безусловно, вопросы несанкционированного размещения отходов на земельных участках являются и частью земельного законодательства. Свалки мелких поселений (поселковые, деревенские, хаотично замусоренные территории, т.н. неконтролируемые свалки), которые состоят в основном из бытовых отходов и мусора, остаются без должного внимания, хотя они не только искажают эстетический вид ландшафта, но могут оказывать и геохимическое воздействие на ОС. Наблюдения показывают, что малые свалки, как правило, не отвечают современным санитарным и техническим нормам. Они сооружаются обычно в придорожных карьерных выемках, низинных частях рельефа, чаще в поймах рек, т.е. в геологической среде, наименее устойчивой к загрязнению продуктами разложения свалочного материала. При этом складирование отходов происходит хаотично, без контроля их состава, без пересыпки изолирующим материалом, часто без дренажньх канав, что усиливает геохимические процессы разложения и распространения загрязнения. Интенсивная миграция химических элементов и их соединений, в т. ч. токсичных и канцерогенных, вызванная процессами активного геохимического выветривания и разложения свалочного материала, приводит к перераспределению и накоплению их во всех компонентах окружающей среды [15]. Особую актуальность в рамках современной переориентации и уклона политики природо- 
пользования в сторону эффективной эколого-экономической сферы, приобретают несанкционированные свалки отходов в водоохранных зонах рек, при чем, территориально такие свалки, по большей части, приурочены к малым населённым пунктам. И на сегодняшний день, можно с уверенностью выделить еще две локальные экологические проблемы современности - проблему долгосрочного несанкционированного размещения отходов в границах землепользования малых населенных пунктов и в водоохранных зонах рек. Что с точки зрения экологического и санитарно-эпидемиологического благополучия населения рассматривается, как нарушение требований санитарной безопасности населенных мест $[9,16]$, а значит, является проблемой современных малых населённых пунктов.

\section{Материалы и методы исследований}

1 января 2019 года республика Адыгея перейдет на новую систему обрашения с ТКО. Регион находится на юге России и значительную его часть занимают особо охраняемые территории, перемежающиеся с селитебными зонами. Поселок Каменномостский располагается Майкопском районе Республики Адыгея в межгорной котловине, на берегу р. Белая. Объем накапливаемых отходов по поселению составляет: твердых бытовых, т/год - 2 136, жидких бытовых, т/год - 6409,8, отходов ЛПУ-А - 7504 кг, Г 13 л., 112 т., Б - 2004 кг. Промышленных, в т. ч.: 1 класс опасности - 1000 л 112 т. 2 класс опасности - 03 класс опасности - 136,6 т/год 4 класс опасности - 2000 т/год. Основными экологическими проблемами территории в числе прочих, является загрязнение и захламление территории твердыми отходами производства и потребления (ТОПП), несанкционированное размещение свалок на землях, представляющих хозяйственную или рекреационную ценность (стихийные свалки) [14].

В ходе полевых исследований в июне 2018 года экспедиционной группой обнаружено место несанкционированного размещения твердых коммунальных отходов в границах поселка Каменномостский в водоохранной зоне р. Белая. Отбор проб почвы в месте несанкционированного складирования отходов осуществлялся в соответствии с ГОСТ 17.4.4.02-84. Охрана природы. Почвы. Отбор проб почвы Методы отбора и подготовки проб для химического, бактериологического, гельминтологического анализа [4]. Схема отбора проб почвы представлена на космическом снимке (рис. 1). Лабораторный анализ произведен в НУЛ «Экоаналитическая лаборатория» кафедры экологии и природопользования СКФУ, на основании ПНД Ф 16.1;2.2;2.3.36-02 Количественный химический анализ почв. Методика выполнения измерений валового содержания меди, кадмия, цинка, свинща, никеля и марганца в почвах [11].

Для оценки суммарного индекса загрязнения почвы применены методические указания МУ 2.1.7.730-99 «Гигиеническая оценка качества почвы 


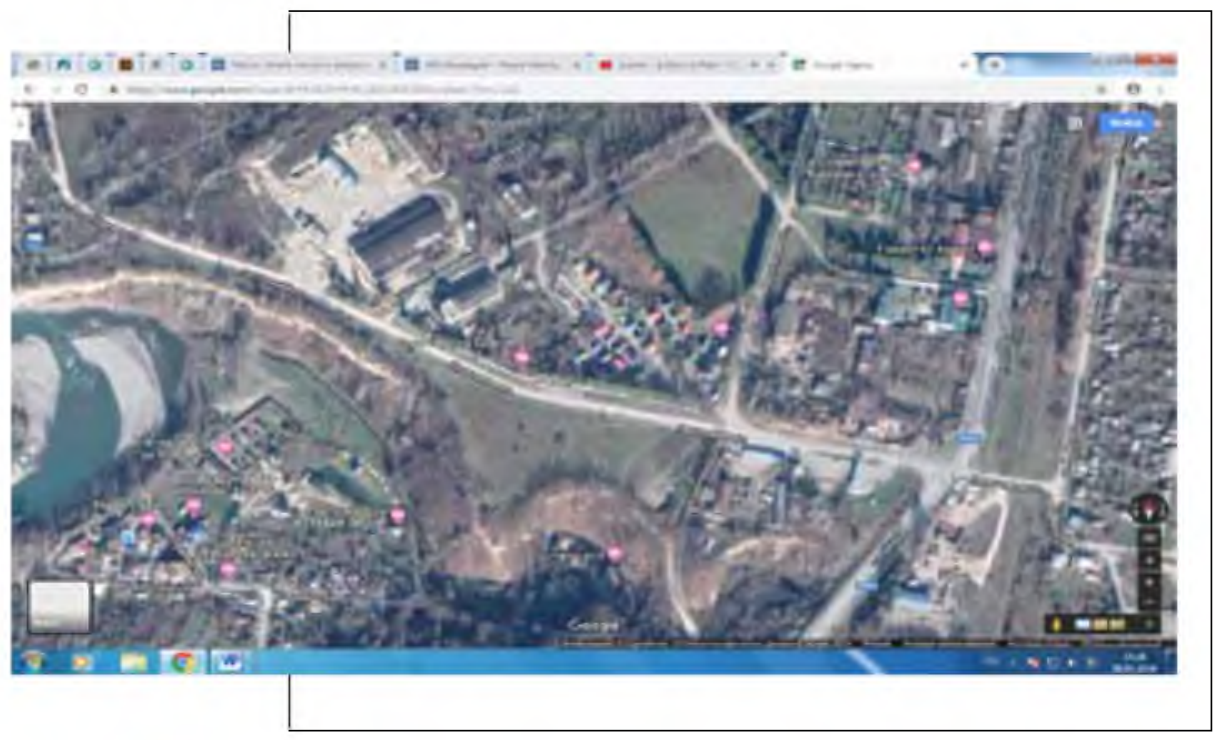

Рис. 1.

Схема отбора проб почвы в водоохраной зоне р. Белая в границах землепользования п.г.т. Каменномостский

Fig. 1 Scheme of soil sampling in the water protection zone $r$. White within the boundaries of land use of the village of Kamennomostsky

населенных мест», который равен сумме коэффициентов концентраций химических элементов-загрязнителей, формула для расчета представлена ниже:

$$
\left.\mathrm{Zc}=\sum \mathrm{Kci}+\ldots+\mathrm{Kcn}\right)-(\mathrm{n}-1)
$$

где $n-$

число определяемых суммируемых вещества;

Kсі - коэффициент концентрации $i$-го компонента загрязнения [6].

Для расчета эколого-экономического ущерба почве, как объекту охраны окружаюшей среды использовались положения Методики исчисления размера вреда, причиненного почвам как объекту охраны окружающей среды, утвержденной Приказом Министерством природных ресурсов и экологии Российской Федерации от 8 июля 2010 г. № 238 [13]. В табл. 1 представлена информация о месте размещения отходов в водоохранной зоне р. Белая в границах п. Каменномостский, полученная во время полевых исследований.

Таблица 1. ИНФОРМАЦИЯ О МЕСТЕ РАЗМЕЩЕНИЯ ОТХОДОВ

$$
\begin{aligned}
& \text { В ВОДООХРАННОЙ ЗОНЕ Р. БЕЛАЯ } \\
& \text { В ГРАНИЦАХ П. КАМЕННОМОСТСКИЙ }
\end{aligned}
$$

Table 1. Information about the location of waste in the water protection zone r. White within the boundaries of the item. Kamennomostsky

\begin{tabular}{l|l|l|l|l}
\hline $\begin{array}{l}\text { Степень химического } \\
\text { загрязнения }\end{array}$ & $\begin{array}{l}\text { Площадь } \\
\text { загрязненного } \\
\text { участка, м }\end{array}$ & $\begin{array}{l}\text { Показатель } \\
\text { в зависимости } \\
\text { от загрязнения } \\
\text { почв } \\
\text { (Приказ №238) }\end{array}$ & $\begin{array}{l}\text { Показатель } \\
\text { в зависимости } \\
\text { от категории } \\
\text { земель } \\
\text { (Приказ №238) }\end{array}$ & $\begin{array}{l}\text { Такса, p/M² } \\
\text { (При каз №238) }\end{array}$ \\
\hline 6,69 & 2295,00 & 1 & 1,8 & 500 \\
\hline
\end{tabular}


Морфологический состав отходов представлен отходами IV и V класса опасности согласно ФККО (табл. 2).

Таблица 2. СВЕДЕНИЯ ОБ ОТХОДАХ НА НЕСАНКЦИИОНИРОВАННОЙ СВАЛКЕ П. КАМЕННОМОСТСКИЙ

Table 2. Waste information on an unauthorized dump Kamennomostsky

\begin{tabular}{|c|c|c|c|c|c|}
\hline Отходы & $\begin{array}{l}\text { Класс } \\
\text { опасности }\end{array}$ & $\begin{array}{l}\text { \%, } \\
\text { содержания }\end{array}$ & $\begin{array}{l}\text { Плотность, } \\
\mathrm{T} / \mathrm{M}^{3}\end{array}$ & $\begin{array}{l}\text { Объем, } \\
\text { M }^{3}\end{array}$ & $\begin{array}{l}\text { Macca, } \\
\mathbf{T}\end{array}$ \\
\hline древесина & V & 50 & 0,60 & 604,35 & 362,61 \\
\hline TKO & IV & 10 & 0,55 & 120,87 & 66,48 \\
\hline Навоз & IV & 5 & 0,40 & 60,435 & 50,76 \\
\hline $\begin{array}{l}\text { Строительные } \\
\text { отходы }\end{array}$ & IV & 35 & 1,20 & 423,05 & 507,66 \\
\hline
\end{tabular}

\section{Результаты исследований и их обсуждение}

Информация о содержании загрязняющих веществ в почве на месте размещения отходов в водоохранной зоне р. Белая в границах п. Каменномостский, которая использовалась для расчета степени химического загрязнения приведена в табл. 3 .

Таблица 3. СОДЕРЖАНИЕ ЗАГРЯЗНЯЮЩИХ ВЕЩЕСТВ В ПОЧВЕ НА МЕСТЕ РАЗМЕЩЕНИЯ ОТХОДОВ В ВОДООХРАННОЙ ЗОНЕ Р. БЕЛАЯ В ГРАНИЦАХ П. КАМЕННОМОСТСКИЙ Table 3. The content of pollutants in the soil at the waste disposal site in the water protection zone $p$. White within the boundaries of the item. Kamennomostsky

\begin{tabular}{|c|c|c|c|c|c|c|c|c|}
\hline \multirow{2}{*}{$\frac{\text { № ח/п }}{1}$} & \multicolumn{8}{|c|}{ Содержание химических веществ, мг/кг } \\
\hline & $\mathrm{Zn}$ & Co & $\mathrm{Pb}^{*}$ & $\mathrm{Fe}^{*}$ & $M n^{*}$ & $\mathrm{Cu}^{*}$ & $\mathrm{Cd}$ & $\mathrm{Ni}^{*}$ \\
\hline 2 & 19,855 & 5,25 & 15,32 & 66,77 & 189,9 & 0,91 & 0,51 & 28,58 \\
\hline 3 & 27.44 & 6,87 & 13,54 & 358,6 & 220,93 & 1,76 & 0,135 & 42,68 \\
\hline 4 & 4,609 & 5,56 & 39,2 & 85,8 & 213,9 & 1,815 & 0,182 & 28,91 \\
\hline 5 & 17,23 & 5,89 & 22,69 & 170,4 & 208,24 & 1,5 & 0,28 & 33,39 \\
\hline среднее & 13,79 & 4,71 & 22,69 & 170,4 & 208,2 & 1,5 & 0,22 & 33,39 \\
\hline фонова & 23,56 & 5,995 & 11,73 & 100,1 & 207,95 & 1,48 & 0,485 & 32,79 \\
\hline
\end{tabular}

* Серым выделено содержание элементов, превышающее фоновые значения и на основании которых рассчитан эколого-экономический ущерб. 
В соответствии с методическими указаниями МУ 2.1.7.730-99 «Гигиеническая оценка качества почвы населенных мест» оценка уровня химического загрязнения почв как индикатора неблагоприятного воздействия на здоровье населения проводится по суммарному показателю загрязнения (Zc) [7].

Суммарный показатель загрязнения $(\mathrm{Zc})$ почвы в водоохранной зоне р. Белая в границах п. Каменномостский равен:

$$
\begin{aligned}
Z c & =\sum\left(\frac{22,69}{11,73}+\frac{170,4}{100,1}+\frac{208,2}{207,95}+\frac{1,5}{1,48}+\frac{33,39}{32,49}\right)-(5-1)= \\
& =(1,93|1,70| 1,00|1,01| 1,03)-4-6,67-4,00-2,67
\end{aligned}
$$

Загрязнение квалифицируется, как допустимое, для населения это означает, что влияние этой свалки оказывает незначительное воздействие на здоровье, здесь может отмечаться наиболее низкий уровень заболеваемости детей и минимальная частота встречаемости функциональных отклонений.

Несмотря на минимальное социально-экологическое влияние, несанкционированные места складирования отходов оказывают негативное воздействие на почвы, как компонент окружающей среды и как объект ее охраны. В последние годы правоприменительная практика основывается на положениях Постановления Пленума Верховного Суда Российской Федерации от 30.11.2017 № 49 «О некоторых вопросах применения законодательства о возмещении вреда, причиненного окружающей среде», которое гласит, что ущерб, причиненный объектам охраны окружающей среды, должен быть взыскан в обязательном порядке [12].

Эколого-экономический ущерб почве, как объекту охраны окружающей среды в результате несанкционированного складирования отходов в водоохранной зоне р. Белая составил 4131000 рублей. Ущерб почве, как объекту охраны окружающей среды от несанкционированного размещения отходов в водоохранной зоне р. Белая составил 8234802 руб. Суммарный ущерб почве, как объекту охраны окружающей среды, в результате несанкционированного складирования отходов в водоохранной зоне р. Белая составил 12365802 руб.

Бюджетным кодексом РФ от 03.12.2012 №244-ФЗ в соответствии с изменениями 2018 года, установлены нормативы распределения взымаемых средств за негативное воздействие на окружающую среду в бюджеты бюджетной системы Российской Федерации в размере: 5\% в федеральный бюджет, $40 \%$ в бюджеты субъектов РФ, 55\% в бюджеты муниципальных районов и городских округов [3].

Таким образом, исходя из обшей суммы рассчитанного ущерба почве, как объекту охраны окружающей среды, в результате несанкционированного складирования отходов в водоохранной зоне р. Белая в границах п. Камен- 
ностский можно рассчитать пополнение бюджетов бюджетной системы РФ на реализацию природоохранных мероприятий (табл. 4).

Таблица 4.

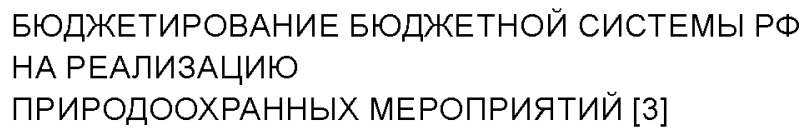

Table 4. Budgeting of the budget system of the Russian Federation for the implementation of environmental measures [3]

\begin{tabular}{l|l|l}
\hline $\begin{array}{l}\text { Федеральный бюджет } \\
(5 \%), \text { руб. }\end{array}$ & $\begin{array}{l}\text { Бюджеты субъектов } \\
\text { Российской Федерации } \\
\text { (40\%), руб. }\end{array}$ & $\begin{array}{l}\text { Бюджеты муниципальных } \\
\text { районов и гороскких } \\
\text { округов (55\%), руб. }\end{array}$ \\
\hline 618290,1 & 4946320,8 & 6801191,1 \\
\hline
\end{tabular}

Таким образом, вывод о том, что возмещение вреда почвам, как объекту охраны окружающей среды в стоимостной форме является эффективным финансовым механизмом по пополнению бюджетов бюджетной системы РФ для мероприятий, направленных на поддержание экологической безопасности государства, очевиден.

В настоящее время в республике Адыгея зарегистрировано 326 свалок. Если предположить, что в среднем это свалки с такой же площадью, как и в п. Каменномостский, то совокупный ушерб почвам составил бы 40312,509млн руб. Эти средства в рамках новой эколого-экономической политики перераспределись бы по бюджетам РФ следующим образом: 2015,63 млн руб. - в федеральный бюджет, 20152,223 млн руб. - в бюджеты субъектов Российской Федерации, 22 171,879 млн руб. - в бюджеты муниципальных районов и городских округов. Учитывая тот факт, что на рекультивацию свалки «Кучино», которую видно из космоса и площадь ее в сотни раз больше, чем свалки в п. Каменномоский, потребуется 2,3 млрд руб., введение действенной системы по предъявлению и возмещению эколого-экономического ущерба позволило бы решить назревшие экологическое вопросы, требующие экономических вливаний. Однако, институт возмещения вреда объектам охраны окружающей среды в стоимостной форме остается малоэффективным и требует пристального внимания и пересмотра законодательной и исполнительной власти РФ [6,8].

\section{Выводы}

В рамках новой эколого-экономической политики, наметившейся в Российской Федерации возмещение вреда, причинённого почве, как объекту охраны окружающей среды, становится существенным экономическим механизмом, способным пополнить бюджеты регионов. В результате перераспределения средств появляется возможность вложений капитала в такие важные для охраны окружающей среды объекты, как мусоросортировочные центры, отходоперерабатывающие комплексы, рекультивационные ме- 
роприятия несанкционированных мест накопления отходов и т.д. Также практика показывает, что в результате рассмотрения дел о возмешении вреда, нанесенного почвам в результате несанкционированного размещения отходов в судах, нередко возникают трудности, в частности, с определением сторон по делу. Как правило, в таких ситуациях ответственность за несанкционированные свалки возлагается на муниципальные образования, как собственников земельных участков.

Однако речь в этом случае ведется не гражданско-правовой ответственности за причинение вреда, а нарушении требований санитарной безопасности населенных мест. Но возмещение ущерба согласно, судебной практики, возлагается целиком на муниципальное образование, поскольку, определить круг виновных лищ не представляется возможным. В таком случае администрация муниципальных образований в порядке регресса и в рамках муниципального земельного контроля вправе установить виновных лиц и предъявить иски о возмешении понесенных расходов, пошедших на возмешение вреда почве. Описанный выше механизм возмешения вреда является довольно действующим и показательным мероприятием по предотвращению несанкционированного размещения отходов. Кроме того с его помощью может быть решены экологические проблемы малых населенных пунктов и водоохранных зон рек, как с точки зрения эколого-экономического механизма, так и с точки зрения превентивных мер.

\section{Библиографический список}

1. Алымова В. А. Возмещение вреда, причиненного почвам: в денежной или натуральной форме // «Справочник эколога». №12. 2017. С. 14-20.

2. Баранова А.Ф. Развитие региональной системы управления отходами // Peгиональная экономика: теория и практика. 2014. №20 (347). С. 35-41.

3. Бюджетный кодекс Российской Федерации от 31.07.1998 N 145-Ф3 (ред. от 28.11.2018).

4. ГОСТ 17.4.4.02-84. Охрана природы. Почвы. Отбор проб почвы Методы отбора и подготовки проб для химического, бактериологического, гельминтологического анализа.

5. Дмитриев Ю. А., Баранова А. Ф. Сфера обращения с отходами: формирование механизмов и институтов управления // Региональная экономика: теория и практика. 2015. №36. С. 46-55.

6. Евграфова И.М., Шубина Е.В., Лаврусевич А.А. Эколого-экономическая оценка хозяйственной деятельности. Практика и перспективы // Известия вузов. Строительство. 2014. № 7. С. 83-87.

7. Методические указания МУ 2.1.7.730-99 «Гигиеническая оценка качества почвы населенных мест» (утв. Главным государственным санитарным врачом РФ 7 февраля 1999 г.).

8. Михеева А.С., Аюшеева С.Н. Сравнительный анализ экономического ущерба окружающей среде на модельных территориях // Вестник ВСГУТУ. 2014. №3 (48). C. 92-97. 
9. Никонов И. С. Правовая природа возмещения вреда, причиненного почвам в результате несанкционированного размещения отходов // Бизнес. Образование. Право (Вестник Волгоградского института бизнеса). 2016. № 3 (36). С. $225-229$

10. Об отходах производства и потребления: Федеральный закон: № 89-ФЗ от 24.06.1998 (в ред. от 03.07.2016 №254-Ф3).

11. ПНДФ 16.1;2.2;2.3.36-02 Количественный химический анализ почв. Методика выполнения измерений валового содержания меди, кадмия, цинка, свинца, никеля и марганца в почвах.

12. Постановления Пленума Верховного Суда Российской Федерации от 30.11.2017 №49 «О некоторых вопросах применения законодательства о возмещении вреда, причиненного окружающей среде».

13. Приказ Министерства природных ресурсов и экологии Российской Федерации от 8 июля 2010 года №238 «Об утверждении Методики исчисления размера вреда, причиненного почвам как объекту охраны окружающей среды».

14. Проектная документация Пояснительная записка. Материалы по обоснованию проекта 07-09М-ПЗ г. Майкоп, 2010 http://ewnc.org/files/adygeya/nerud/ Hadzhoh-Genplan_tom1.3.pdf.

15. Филиппова Л.А., Юркова И.В. Геохимическое влияние малых свалок на окружающую среду // Известия Сибирского отделения Секции наук о Земле PAEH. 2009. №1 (34). C. 92-106.

16. Шелухина Е. А. Применение экономических инструментов для нейтрализации экологического ущерба в региональном аспекте // Региональная экономика: теория и практика. 2016 . №37 (316). С. 34-43.

\section{References}

1. Alymova V. A. Compensation of damage caused to the soil: in cash or in kind // "Ecologist's Handbook". №12. 2017. p. 14-20.

2. Baranova A.F. Development of a regional waste management system // Regional economy: theory and practice. 2014. No. 20 (347). Pp. 35-41.

3. Budget Code of the Russian Federation of 07/31/1998 N 145-FZ (as amended on 11/28/2018). 4. GOST 17.4.4.02-84. Protection of Nature. Soils. Soil sampling Methods of sampling and sample preparation for chemical, bacteriological, and helminthological analysis.

4. Dmitriyev YU. A., Baranova A. F. Sfera obrashcheniya s otkhodami: formirovaniye mekhanizmov i institutov upravleniya // regiongal'naya ekonomika: teoriya i praktika. 2015. №36. S. 46-55.

5. Yevgrafova I.M., Shubina Ye.V., Lavrusevich A.A. Ekologo-ekonomicheskaya otsenka khozyaystvennoy deyatel'nosti. Praktika i perspektivy // Izvestiya vuzov. Stroitel'stvo. 2014. № 7. S. 83-87.

6. Metodicheskiye ukazaniya MU 2.1.7.730-99 «Gigiyenicheskaya otsenka kachestva pochvy naselennykh mest» (utv. Glavnym gosudarstvennym sanitarnym vrachom RF 7 fevralya 1999 g.).

7. Mikheyeva A.S., Ayusheyeva S.N. Sravnitel'nyy analiz ekonomicheskogo ushcherba okruzhayushchey srede na model'nykh territoriyakh // Vestnik VSGUTU. 2014. № 3 (48). S. 92-97.

8. Nikonov I.S. The legal nature of compensation for harm caused to the soil as a result of unauthorized disposal of waste // Business. Education. Right. Bulletin of the Volgograd Institute of Business. 2016. № 3 (36). Pp. 225-229. 
9. On production and consumption wastes: Federal Law: No. 89-Ф3 dated 06.24.1998 (as amended on 03.07.2016 №254-Ф3).

10. PND F $16.1 ; 2.2 ; 2.3 .36-02$ Quantitative chemical analysis of soils. Methods for measuring the total content of copper, cadmium, zinc, lead, nickel and manganese in soils.

11. Decisions of the Plenum of the Supreme Court of the Russian Federation of 30.11.2017 No. 49 "On some issues of the application of legislation on compensation for environmental damage".

12. Order of the Ministry of Natural Resources and Environment of the Russian Federation dated July 8, 2010 № 238 "On approval of the Method for calculating the amount of damage caused to the soil as an object of environmental protection".

13. Project documentation Explanatory note. Materials on the justification of the project 07-09M-PZ Maikop, $2010 \mathrm{http} / /$ ewnc. org/files/adygeya/nerud/HadzhohGenplan_tom1.3.pdf.

14. Filippova L.A., Yurkova I.V. Geochemical influence of small landfills on the environment // News of the Siberian Branch of the Earth Sciences Section of the Russian Academy of Natural Sciences. 2009. №1 (34). P. 92-106.

15. Shelukhina, E. A. [The use of economic instruments to neutralize environmental damage in a regional perspective]. Regional Economics: Theory and Practice. 2016. №37 (316). P. 34-43.

Рукопись поступила в редакцию 13.05.2019 г. Принята к публикации 01.06.2019 г.

\section{6 aвторах}

Бегдай Инна Владимировна, кандидат технических наук, доцент, доцент кафедры экологии и природопользования СевероКавказского федерального университета.

г. Ставрополь, ул. Пушкина, 1, корп. 2, ауд. 212.

E-mail: algae@mail.ru, тел. 89187461332

Блужина Анастасия Сергеевна, научный сотрудник НУЛ «Экоаналитическая лаборатория» СКФУ, Северо-Кавказский фредеральный университет, г. Ставрополь, ул. Пушкина, 1, корп. 2, ауд. 334. E-mail: institutka-aska@mail.ru (вести переписку).

Тел. 89624037577

Иваненко Ксения Ивановна, инженер-лаборант НУЛ «Экоаналитическая лаборатория» СКФУ, Северо-Кавказский федеральный университет, г. Ставрополь, ул. Пушкина, 1, корп. 2, ауд. 334,

E-mail: k.ivanenko.ivanovna@mail.ru , Тел. 8-962-014-87-24

Харин Константин Викторович, кандидат географических наук, доцент и.о. заведующего кафедры экологии и природопользования Северо-Кавказский федеральный университет, г. Ставрополь, ул. Пушкина, 1, корп. 2, ауд. 327.

E-mail: k-harin79@mail.ru.

Тел. 89620165248. 


\section{About the authors}

Begday Inna. Candidate of Technical Sciences, Associate Professor, Associate Professor of the Department of Ecology and Environmental Sciences North Caucasian Federal University, Stavropol, st. Pushkin, 1, Bldg. 2, room. 212

E-mail: algae@mail.ru.

Tel. 89187461332.

Bluzhina Anastasiya. Researcher place of work North Caucasian Federal University, Stavropol, st. Pushkin, 1, Bldg. 2, room. 334.

E-mail: institutka-aska@mail.ru.

Tel. 89624037577.

Ivanenko Ksenia Ivanovna, engineer laboratory ZERO «Ecoanalytical laboratory, North Caucasus Federal University, Stavropol, Pushkin str., 1 , korp. 2, AUD. 334.

E-mail: k.ivanenko.ivanovna@mail.ru.

Tel. 8-962-014-87-24.

Kharin Konstantin Viktorovich. Candidate of Geographical Sciences, Associate Professor And about. Head of the Department of Ecology and Environmental Management North Caucasus Federal University, Stavropol, st. Pushkin, 1, Bldg. 2, aud. 327.

E-mail: k-harin79@mail.ru.

Tel. 89620165248

$\prod_{b}$

Издательство Северо-Кавказского

федерального университета.

г. Ставрополь, ул. Пушкина, 1.

Корректор - М.И. Толмачев.

Компьютерная верска - О.Г. Полевич.

Подписано в печать 29.06.2019 г. Выход в свет 12.07.2019 г. Формат $70 \times 108$ 1/16. Гарнитура Times New Roman. Бумага офсетная. Усл. печ. л. 15,5. Тираж 1000 экз. ЦЦена 534 руб.

Отпечатано в Издательско-полиграфическом комплексе ФГАОУВО «Северо-Кавказскийфедеральныйуниверситет». 355029, г. Ставрополь, пр-т Кулакова, 2. 